\title{
AIMSeT: Advanced Innovative Materials Selection Techniques
}

\author{
Christopher C. Ibeh, Dhirendra Bhattarai \\ Pittsburg State University, Pittsburg, KS 66762
}

\begin{abstract}
Basic materials selection techniques typically yield more than one to several suitable materials for a given product, part or application based on pre-specified property requirements and processing method(s). Some of the advanced innovative materials selection techniques recognize that the pre-specified properties do not have the same level of importance in a given design or application. These innovative techniques such as the digital logic approach (DLA) and the life cycle value analysis (LCVA) methods operate on the basis of assigning expertly, pre-determined weighting factors to the prespecified properties to portray their levels of importance. The weighting factor approach makes it possible to rank pre-selected materials in order of suitability. This paper discusses the successful and innovative use of the DLA and LCVA techniques, as part of the "advanced engineering materials," graduate engineering technology course at Pittsburg State University (PSU), in the materials selection for the housings of signal and radar detection units. It is the authors' position that the costs/performance-importance of materials in product, process and system' design and development dictate that material selection be accorded priority and more attention in engineering technology and SMET curricula and education.
\end{abstract}

\section{Introduction}

One of the current trends in the industry is the focus on "costs" as one of the dominant design factors or criteria ${ }^{(1)(2)(3)}$. Materials costs account for majority of the development and production costs; it is not uncommon for materials costs to account for more than fifty percent of development and production costs. Materials costs is typically about $50 \%$ in the ship building industry, and about $60 \%$ in the aerospace industry, and $70 \%$ in the automotive industry ${ }^{(2)(3)(4)(5)}$. The implication of this is that materials selection is critical in any design or production process. Incorrect materials selection can result in difficulty of processing, inadequate product performance and ultimately increase in costs. Appropriate cost estimate include not only the initial materials costs but the fabrication, installation, transportation, disposal/recycling and penalty costs.

The materials selection situation is compounded by the availability of many types and grades of materials such as biomaterials, ceramics, composites, metals, polymers/plastics, wood and others that exhibit variability in property levels, processing requirements and costs. A good materials selection process takes into account these variations in 
characteristics and requirements. Most basic selection techniques accomplish this very easily, and often times yield more than one to several suitable materials for a given application, product or part. Some materials selection techniques take into consideration that the properties and requirements used do not always have the same levels of importance with respect to actual performance. These materials selection techniques such as the digital logic approach (DLA), life cycle value analysis (LCVA) and others that utilize a "weighted property system" (WPS) are considered advanced and innovative, and have the capability to rank suitable materials for a given application in order of suitability. The in-built "normalization" strategy of the WPS is tantamount to benchmarking, and provides ease of comparison of materials on an equivalent base.

Considering this apparent importance of materials and materials selection in process and system design, the concept of advanced innovative materials selection techniques has been incorporated as a core component of the "advanced engineering materials" course at Pittsburg State University. This move takes into account that most engineering technology and SMET careers involve one form or another of design, development, production, marketing/distribution and usage of products, parts and processes.

Goals and Objectives

The objectives of this paper are to:

i. discuss the materials selection process,

ii. highlight the concept of specific strength or "strength to weight ratio" as the critical parameter for structural applications,

iii. discuss the innovative use of the weighted property system (WPS) in materials selection,

iv. discuss case studies of the use of the digital logic approach (DLA) and life cycle value analysis (LCVA) in the materials selection for the housings of signal and radar detection units, and

v. advocate the "high level priority" inclusion of materials selection in engineering technology and SMET curricula and education.

\section{The Materials Selection Process}

The material selection process typically consists of four major stages:

1. Materials Requirements Analysis

2. Identification and Screening of suitable materials

3. Evaluation of acceptable materials

4. Development of design database.

Material selection occurs in all phases of process or system design but its effect is more critical at the end phases. The recommended approach is to consider a very wide array of materials at the early phases. The number of materials is reduced in the second phase of the material selection process.

Proceedings of the 2003 American Society for Engineering Education Annual Conference \& Exposition Copyright $($ C 2003, American Society for Engineering Education 


\subsection{Materials Requirement Analysis}

The materials requirements analysis phase answers the question(s): what are the conditions of service and the operating environment that the product is expected to endure? These conditions are specified and translated into known, critical material properties. The properties of a given material are determined by its composition and structure. The properties and characteristics of a material in turn determine the applications and service performance of a given part or product. Table T.I shows the specific strength of materials and different categories of materials; specific strength or "strength to weight ratio", (7)(9)(10)(11)(12)(13)(14) is the most appropriate parameter for assessing materials on a one-on-one basis in structural applications. As can be seen from the ninth and tenth columns of Table T.I, specific strength and specific modulus have the appropriate units of length; specific strength and specific modulus can also have strength units of Psi or Mpa if the denominator, weight, is represented as specific gravity rather than density as is in this case.

Table T.2 shows the inter-relationship between materials' performance, failure modes and properties ${ }^{(2)(3)(7)}$. In certain cases, the performance and failure mode is determined by more than one property. This is also true for operating and service conditions in which more than one environment may be controlling. The material characteristic referred to as stiffness is critical in structural applications, and is specifically and quantitatively represented by the parameter, modulus of elasticity (E) or as afore mentioned by specific modulus. The properties modulus and compressive strength are the criteria for assessing the buckling condition of a structural column or column under load.

For correct materials selection, it is typical to formalize material properties requirements via design specifications such as performance specifications and product specifications. Performance specification deals with functionality or the ability of a material to do the designated job, and evaluation of risks and consequences of failure. Product specification, on the other hand, deals with product components manufacturing and procurement conditions with emphasis on material properties.

\subsection{Identification and Screening of Suitable Materials}

This stage of the materials selection process can be accomplished via the use of:
i. the popular Ashby Charts,
ii. basic softwares, and
iii. in-house expertise.

The very popular Ashby Charts (one form is shown below) provide very easy means of identifying and screening suitable materials for a given application. The Ashby Chart shown below can be used to identify suitable materials for "simple axial loading", "buckling of slender column" and "bending of plate" applications by simply using the modulus of elasticity (E) and density $(\rho)$ of a material as points of entry at the ordinate 


\begin{tabular}{|c|c|c|c|c|c|c|c|c|c|}
\hline \multicolumn{10}{|c|}{ Table T.I: Specific Strength of Materials } \\
\hline $\begin{array}{c}\text { Material } \\
\qquad \downarrow\end{array}$ & \begin{tabular}{|c|} 
Melt \\
Temp. \\
$\mathrm{T}_{\mathrm{m}}$ \\
$\left({ }^{0} \mathrm{C}\right)$ \\
\end{tabular} & $\begin{array}{r}\text { Den } \\
(\mathrm{g} / \mathrm{cc})\end{array}$ & $\begin{array}{l}\text { sity }(\rho) \\
\text { (pci) }\end{array}$ & $\begin{array}{r}\text { Te } \\
\text { Stre } \\
\text { (MPa) }\end{array}$ & $\begin{array}{l}\text { sile } \\
\text { ngth } \\
\text { (psi) }\end{array}$ & $\begin{array}{l}\text { Modulus } \\
\text { (MPa) }\end{array}$ & $\begin{array}{l}\text { Modulus } \\
\text { (psi) }\end{array}$ & $\begin{array}{c}\text { T.S./ } \rho \\
\text { Specific } \\
\text { Strength } \\
\text { (in) }\end{array}$ & \begin{tabular}{|c} 
E/ $\rho$ \\
Specific \\
Modulus \\
(in)
\end{tabular} \\
\hline Beryllium & 1285 & 1.84 & 0.0666 & 448 & 65000 & 303000 & $4.39 \mathrm{E}+07$ & 975976 & $6.60 \mathrm{E}+08$ \\
\hline Titanium & 1670 & 4.5 & 0.163 & 220 & 31900 & $1.16 \mathrm{E}+05$ & $1.68 \mathrm{E}+07$ & 195706 & $1.03 \mathrm{E}+08$ \\
\hline \begin{tabular}{|c|} 
S-Steel \\
T S20000 Series )
\end{tabular} & & 7.85 & 0.284 & 1110 & 161000 & $1.71 \mathrm{E}+05$ & $2.5 \mathrm{E}+07$ & 566901 & $8.74 \mathrm{E}+07$ \\
\hline \begin{tabular}{|c|} 
C-Steel \\
AISI 1000 Series )
\end{tabular} & & 7.872 & 0.284 & 330 & 47900 & $2.05 \mathrm{E}+05$ & $2.97 \mathrm{E}+07$ & 168662 & $1.05 \mathrm{E}+08$ \\
\hline Aluminum & 646-657 & 2.705 & 0.0977 & 76 & 11000 & $6.90 \mathrm{E}+04$ & $1.00 \mathrm{E}+07$ & 112590 & $1.02 \mathrm{E}+08$ \\
\hline Nickel & 1455 & 8.88 & 0.321 & 317 & 46000 & 207000 & $3.00 \mathrm{E}+07$ & 143302 & $9.35 \mathrm{E}+07$ \\
\hline Copper & 1084 & 8.96 & 0.324 & 210 & 30500 & $1.10 \mathrm{E}+05$ & $1.60 \mathrm{E}+07$ & 94136 & $4.92 \mathrm{E}+07$ \\
\hline Silver & 961 & 10.491 & 0.379 & 140 & 20300 & 76000 & $1.10 \mathrm{E}+07$ & 53562 & $2.91 \mathrm{E}+07$ \\
\hline Tin & 232 & 6.45 & 0.233 & 220 & 31900 & 41400 & 6004656 & 136910 & $2.58 \mathrm{E}+07$ \\
\hline Gold & 1064.43 & 19.32 & 0.698 & 120 & 17400 & 77200 & $1.12 \mathrm{E}+07$ & 24928 & $1.60 \mathrm{E}+07$ \\
\hline Lead & 328 & 11.34 & 0.41 & 18 & 2610 & 14000 & 2030560 & 6366 & $4.95 \mathrm{E}+06$ \\
\hline \multicolumn{10}{|l|}{ Ceramics } \\
\hline $\begin{array}{c}\text { Silicon Carbide } \\
\text { (SiC) } \\
\text { (sapco si) }\end{array}$ & 2600 & 3.1 & 0.112 & 390 & 56600 & 410000 & $5.95 \mathrm{E}+07$ & 505357 & $5.31 \mathrm{E}+08$ \\
\hline Alumina $\left(\mathrm{Al}_{2} \mathrm{O}_{3}\right)$ & 2030 & 3.96 & 0.143 & 300 & 43500 & 370000 & $5.37 \mathrm{E}+07$ & 304196 & $3.75 \mathrm{E}+08$ \\
\hline Mica & & 2.5 & 0.0903 & 41 & 5950 & 76000 & $1.10 \mathrm{E}+07$ & 65892 & $1.22 \mathrm{E}+08$ \\
\hline $\begin{array}{c}\text { Titania }\left(\mathrm{TiO}_{2}\right) \\
(\text { CeramTec } \\
\text { Grade } 192 \text { Tan })\end{array}$ & 1920 & 4 & 0.145 & 51.6 & 7480 & 228000 & $3.31 \mathrm{E}+07$ & 51586 & $2.28 \mathrm{E}+08$ \\
\hline $\begin{array}{c}\text { Zirconia }\left(\mathrm{ZrO}_{2}\right) \\
(\text { CeramTec } \\
\text { Grade } 848)\end{array}$ & $681-2847$ & 6 & 0.217 & 551 & 79900 & 186000 & $2.70 \mathrm{E}+07$ & 368203 & $1.24 \mathrm{E}+08$ \\
\hline $\begin{array}{c}\text { Boron Nitride } \\
\text { (BN) }\end{array}$ & 3027 & 3.49 & 0.126 & & & & & & \\
\hline $\begin{array}{c}\text { Boron Carbide } \\
\left(\mathrm{B}_{4} \mathrm{C}\right)\end{array}$ & 2350 & 2.5 & 0.0903 & & & & & & \\
\hline Silica $\left(\mathrm{SiO}_{2}\right)$ & & 2.65 & 0.0957 & & & & & & \\
\hline $\begin{array}{l}\text { Titanium Carbide } \\
\text { (TiC) }\end{array}$ & 3065 & 4.94 & 0.178 & 258 & 37400 & $448000-451000$ & $\begin{array}{c}65000000- \\
5400000\end{array}$ & 210112 & $\begin{array}{l}365168539- \\
367415730\end{array}$ \\
\hline \multicolumn{10}{|l|}{$\begin{array}{c}\text { Glass } \\
\text { Materials }\end{array}$} \\
\hline Fused Silica & & 2.2 & 0.0795 & & & $70000-78000$ & $\begin{array}{l}10200000- \\
11300000\end{array}$ & & $\begin{array}{l}128301887- \\
142138365\end{array}$ \\
\hline Vycor & & 2.18 & 0.0788 & & & 68000 & 9860000 & & $1.25 \mathrm{E}+08$ \\
\hline
\end{tabular}

Proceedings of the 2003 American Society for Engineering Education Annual Conference \& Exposition Copyright (C) 2003, American Society for Engineering Education 
Table T.I (Continued): Specific Strength of Materials

\begin{tabular}{|c|c|c|c|c|c|c|c|c|c|}
\hline Material & \begin{tabular}{|l|} 
Melt \\
Temp.
\end{tabular} & Den & sity $(\rho)$ & & $\begin{array}{l}\text { nsile } \\
\text { ength }\end{array}$ & & & T.S./ $\rho$ & $\mathbf{E} / \rho$ \\
\hline \begin{tabular}{c|c} 
Pyrex \\
(Borosilicate)
\end{tabular} & & 2.4 & 0.0867 & & & $\begin{array}{l}60000- \\
64000\end{array}$ & $\begin{array}{l}8700000- \\
9280000\end{array}$ & & $\begin{array}{l}100346021- \\
107035755\end{array}$ \\
\hline Pyroceram & & & & & & & & & \\
\hline Polymers & & & & & & & & & \\
\hline HDPE & $110-135$ & $0.918-1.4$ & $332-0.050$ & $10-50$ & $1450-7250$ & $180-1600$ & $\begin{array}{l}26100- \\
232000\end{array}$ & $\begin{array}{l}28656- \\
218373\end{array}$ & $\begin{array}{l}515810- \\
6987952\end{array}$ \\
\hline ABS m-impact & & $1.02-1.22$ & $368-.0441$ & $30-138$ & $4350-20000$ & $1700-2400$ & $\begin{array}{l}247000- \\
348000\end{array}$ & $\begin{array}{l}98639- \\
543478\end{array}$ & $\begin{array}{l}5600907- \\
9456522\end{array}$ \\
\hline Polystyrene & & $1.04-1.07$ & $376-.0387$ & $17.9-70$ & $2600-10200$ & $1790-3380$ & $\begin{array}{l}260000- \\
490000\end{array}$ & $\begin{array}{l}67183- \\
271277\end{array}$ & $\begin{array}{l}6718346- \\
13031915\end{array}$ \\
\hline Polycarbonate & $230^{*}$ & $1.17-1.45$ & $423-0.052$ & $54-72$ & $7830-10400$ & $1600-2400$ & $\begin{array}{l}232000- \\
348000\end{array}$ & $\begin{array}{l}149427- \\
245863\end{array}$ & $\begin{array}{l}4427481- \\
8226950\end{array}$ \\
\hline Nylon-66 & 265 & $1.03-1.16$ & $372-0.041$ & $40-85.5$ & $5800-12400$ & $700-3300$ & $\begin{array}{l}102000- \\
479000\end{array}$ & $\begin{array}{l}138425- \\
333333\end{array}$ & $\begin{array}{l}2434368- \\
12876344\end{array}$ \\
\hline Polyacetal & 175 & & & & & & & & \\
\hline PPS & $280-290$ & $1.34-1.8$ & 0484-0.06 & $69-124$ & $0000-18000$ & $2200-5500$ & $\begin{array}{l}319000- \\
798000\end{array}$ & $\begin{array}{l}153846- \\
371901\end{array}$ & $\begin{array}{l}4907692- \\
6487603\end{array}$ \\
\hline PTFE & 330 & $2.15-2.3$ & $777-0.083$ & $10-43$ & $1450-6240$ & $400-1800$ & $\begin{array}{l}58000- \\
261000\end{array}$ & $\begin{array}{l}17449- \\
80309\end{array}$ & $\begin{array}{l}697954- \\
3359073\end{array}$ \\
\hline $\begin{array}{c}\text { Polysulfones } \\
\text { (amorphous T.P.) }\end{array}$ & & $1.2-1.4$ & & & & $\begin{array}{l}10000- \\
25800\end{array}$ & 360000 & $8333-18429$ & $\begin{array}{l}260900- \\
300000\end{array}$ \\
\hline $\begin{array}{l}\text { Polyetherimide } \\
\text { (PEI) } \\
\text { (amorphous T.P) }\end{array}$ & & 1.3 & & & & 14000 & & 10800 & \\
\hline $\begin{array}{c}\text { Glass Fiber-Filled } \\
\text { PEI }\end{array}$ & & & & & & 28000 & & 21540 & \\
\hline $\begin{array}{l}\text { Carbon Fiber- } \\
\text { Filled PEI }\end{array}$ & & & & & & 34000 & & 26150 & \\
\hline Phenolics & & $1.28-2.13$ & $0462-0.07$ & $53.5-60$ & $7760-8700$ & $4100-8640$ & $\begin{array}{l}595000- \\
1250000\end{array}$ & $\begin{array}{l}100779- \\
188312\end{array}$ & $\begin{array}{l}7727273- \\
27056277\end{array}$ \\
\hline $\begin{array}{c}\text { Fibers -- } \\
\text { Reinforcements }\end{array}$ & & $\mathrm{KN} / \mathrm{m}^{3}$ & & $\mathrm{GN} / \mathrm{m}^{2}$ & & $\mathrm{GN} / \mathrm{m}^{2}$ & & & \\
\hline Carbon Fiber & 3650 & 13.8 & $4.99 \mathrm{E}-04$ & 1.7 & 246568 & 190 & $2.76 \mathrm{E}+07$ & $4.94 \mathrm{E}+08$ & $5.53 \mathrm{E}+10$ \\
\hline Graphite & 3650 & 13.8 & $4.99 \mathrm{E}-04$ & 1.7 & 246568 & 250 & $3.63 \mathrm{E}+07$ & $4.95 \mathrm{E}+08$ & $7.27 \mathrm{E}+10$ \\
\hline S-Glass Fiber & 1725 & 24.4 & $8.82 \mathrm{E}-04$ & 4.8 & 696192 & 86 & $1.25 \mathrm{E}+07$ & $7.90 \mathrm{E}+08$ & $1.42 \mathrm{E}+10$ \\
\hline E-Glass Fiber & 1725 & 25 & $9.03 \mathrm{E}-04$ & 3.4 & 493136 & $\overline{72}$ & $1.04 \mathrm{E}+07$ & $5.46 \mathrm{E}+08$ & $1.16 \mathrm{E}+10$ \\
\hline
\end{tabular}

Legend - Table T.I:

Mica .. Complex Potassium Silicates $\left(\mathrm{K}_{2} \mathrm{~A}_{44}\right)\left(\mathrm{A}_{12} \mathrm{Si}_{6} \mathrm{O}_{20}\right)(\mathrm{OH})_{4}$; Fused Silica $\left(\right.$ Quartz)..99\% $\mathrm{SiO}_{2}$; Vycor . 96\% $\mathrm{SiO}_{2}, 4 \% \mathrm{~B}_{2} \mathrm{O}_{3}$; Pyrex (Borosilicate) .. 81\% $\mathrm{SiO}_{2}, 12 \% \mathrm{~B}_{2} \mathrm{O}_{3}, 4 \% \mathrm{Na}_{2} \mathrm{O}, 2 \% \mathrm{Al}_{2} \mathrm{O}_{3}$; Soda Lime Gen. Purpose Glass 74\% $\mathrm{SiO}_{2}, 15 \% \mathrm{Na}_{2} \mathrm{O}, 5 \% \mathrm{CaO}, 4 \% \mathrm{MgO}, 1 \% \mathrm{Al}_{2} \mathrm{O}_{3}$ Pyroceram ... Crystalline Glass; more like ceramics and are based on lithium oxide, magnesium oxide and aluminum oxide with titania as nucleating agent.

Proceedings of the 2003 American Society for Engineering Education Annual Conference \& Exposition Copyright (C) 2003, American Society for Engineering Education 
and abscissa of the chart. Materials that fall on the $\left(E^{0.5} / \rho=C\right)$ line, for example, have equal suitability for a "buckling" application; materials that lie above the $\left(\mathrm{E}^{0.5} / \rho=\mathrm{C}\right)$ line have superior "buckling" properties to those on or below the line. The chart indicates that carbon fiber and glass fiber reinforced plastics (CFRP, GFRP) are more suitable than aluminum and nickel alloys in slender column loading applications. The $(E / \rho=C)$ and $\left(\mathrm{E}^{0.33} / \rho=\mathrm{C}\right)$ plots represent the simple axial loading and plate bending situations respectively. Ashby charts have plots for application situations other than just the ones stated above ${ }^{(17)}$.

\begin{tabular}{|c|c|c|c|c|c|c|c|c|c|c|c|c|c|c|}
\hline \multicolumn{15}{|c|}{ Table T.2: Critical Material Properties } \\
\hline \multirow{2}{*}{$\begin{array}{l}\text { Performance/ } \\
\text { Failure } \\
\text { Type }\end{array}$} & \multicolumn{14}{|c|}{ Material Property } \\
\hline & 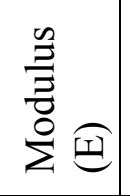 & 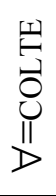 & 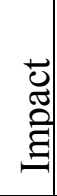 & & $F^{b 0}$ & $\begin{array}{l}\tilde{0} \\
\tilde{\Xi} \\
\tilde{\Xi} \\
\tilde{z} \\
\tilde{0}\end{array}$ & $\underline{U}$ & $\sum^{\infty}$ & 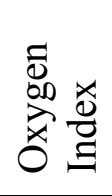 & 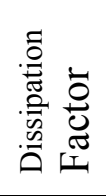 & 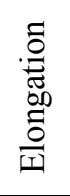 & 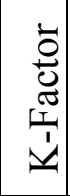 & 总 & 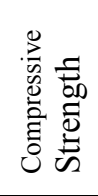 \\
\hline Stiffness & $\mathrm{X}$ & & & & & & & & & & & & & \\
\hline Buckling & $\mathrm{X}$ & & & & & & & & & & & & & $\mathrm{X}$ \\
\hline $\begin{array}{l}\text { Brittle } \\
\text { Fracture }\end{array}$ & & & $\mathrm{x}$ & & $\mathrm{x}$ & & $\mathrm{x}$ & & & & & & & \\
\hline $\begin{array}{l}\text { Dimensional } \\
\text { Stability }\end{array}$ & & $\mathrm{X}$ & & & & & & $\mathrm{X}$ & & & $\mathrm{X}$ & & & \\
\hline Flammability & & & & & & & & & $\mathrm{X}$ & & & & & \\
\hline Toughness & & & & & & & & & & & $\mathrm{X}$ & & & \\
\hline $\begin{array}{l}\text { Electrical } \\
\text { Insulation }\end{array}$ & & & & & & $\mathrm{x}$ & & & & $\mathrm{x}$ & & & & \\
\hline $\begin{array}{l}\text { Thermal } \\
\text { Insulation }\end{array}$ & & & & & & & & & & & & $\mathrm{x}$ & & \\
\hline $\begin{array}{l}\text { Environmental } \\
\text { Stress Cracking }\end{array}$ & & & & & & & $\mathrm{x}$ & & & & & & $\mathrm{x}$ & \\
\hline $\begin{array}{l}\text { Thermal } \\
\text { Fatigue }\end{array}$ & $\mathrm{X}$ & $\mathrm{x}$ & & $\mathrm{x}$ & & & & & & & & $\mathrm{x}$ & & \\
\hline $\begin{array}{l}\text { EMI/RFI } \\
\text { Shielding }\end{array}$ & & & & & & $\mathrm{x}$ & & & & & & & & \\
\hline \multicolumn{15}{|c|}{$\begin{aligned} \mathrm{K}_{\mathrm{IC}}= & \text { Plain Strain Critical Stress Intensity Factor } \cong \mathrm{K}_{\mathrm{C}}=\sigma_{\mathrm{F}}(\pi \mathrm{h})^{0.5}=\left(\mathrm{EG}_{\mathrm{F}}\right)^{0.5} \\
& \text { [ Plot of } \mathrm{K}_{\mathrm{C}} \text { versus thickness }(\mathrm{h}) \text { Yields } \mathrm{K}_{\mathrm{IC}} \text { Values Lower Than } \mathrm{K}_{\mathrm{C}} \text { That Is } \\
& \text { Independent of Thickness }(\mathrm{h}) ; \mathrm{K}_{\mathrm{IC}}=\text { Intrinsic Form of } \mathrm{K}_{\mathrm{C}} \text { ] }\end{aligned}$} \\
\hline \multicolumn{15}{|c|}{$\mathrm{G}_{\mathrm{F}}=$ Fracture Toughness $; \quad \mathrm{K}_{\mathrm{IC}}=$ True Representation of Fracture Toughness $<\mathrm{K}_{\mathrm{C}}$. } \\
\hline \multicolumn{15}{|c|}{$\begin{array}{l}\text { M.S. = Mold Shrinkage; } \quad \mathrm{T}_{\mathrm{g}}=\text { Glass Transition Temperature; } \\
\text { Conductance = Electrical Conductivity or Resistivity; K-Factor = Thermal Conductivity } \\
\text { Impact = Impact Strength/Energy; } \quad \text { TSI = Thermal Shock Index }=\left(\sigma^{*} \mathrm{~K} / \forall^{*} \mathrm{E}\right) \\
\forall=\text { COLTE = Coefficient of Linear Thermal Expansion; } \quad \sigma=\text { Tensile Strength }\end{array}$} \\
\hline
\end{tabular}


Several softwares are available in the market for materials selection based on prespecified property requirements for a given application; these will typically yield several suitable materials for a given search. The GE Polymerland software: (http://www.gepolymerland.com), Steel Weights software: (http://www.steelforge.com), Ceramics and Industrial Materials software: http://www.ceramics.com/, The Composites Corner: http://advmat.com/othsites.html, Composites Registry software: http://www.compositesreg.com/, and others are very good materials databases $^{(18)(19)(20)(21)(22)}$.

It is also common practice for company experts to meet and pre-select materials for a given application based on their materials expertise. Materials scientists, engineers, technologists, purchasing managers, designers and tool makers develop certain levels of materials expertise with years of experience in their jobs, working with materials and Materials' suppliers, and are good candidates for membership in a materials selection committee or team. Identified and pre-selected materials are then subjected to the evaluation phase of the materials election process.

\subsection{Evaluation of Pre-Screened Acceptable Materials}

Four major approaches/methods are used in the evaluation of pre-screened acceptable materials; these are the:
a. Performance-Cost Index (PCI),
b. Failure Analysis.
c. Digital Logic Approach (DLA), and
d. Life Cycle Value Analysis (LCVA).

2.3.a. The performance cost index (PCI) approach is based on the concept of maximization of performance while minimizing cost and weight ${ }^{(23)}$. This method while popular has the limitation that it uses only one parameter to represent performance, and most often times it is based on the specific strength or "strength-to-weight ratio" parameter afore discussed as per Table T.I.

2.3.b. The failure analysis method is very popular in the aerospace, electronics and high performance systems. It is customary for companies in the aerospace and electronic industries to carry out non-destructive testing programs for their products in order to ensure high quality performance. The Raytheon's fabrication plant in Wichita, Kansas ultra-sonically tests its aircraft components and parts prior to use in the assembly and production. Other non-destructive, destructive and simulation testing programs are employed in the industry. The plastics testing lab at Pittsburg State University is currently undertaking a project, in collaboration with Able Manufacturing Corp., Joplin, MO, to develop a "J-Integral Method for Fracture Toughness of Composites ${ }^{(24)}$." 
Session 1649

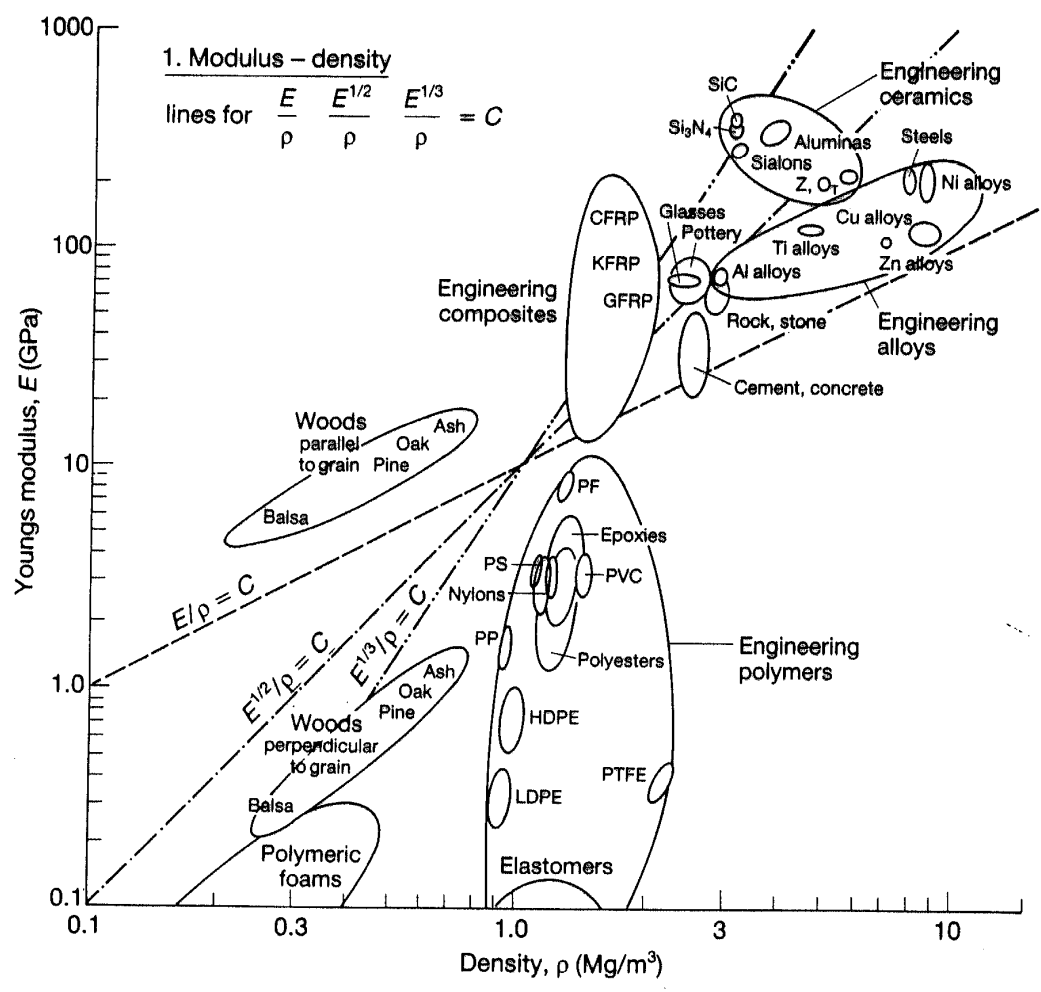

(a)

Ashby Charts: Modulus Versus Density (Specific Modulus Charts)

(Taken From: (1). Ashby, Michael F., "Materials in Mechanical Design," Journal of Materials Education. Volume 15, Page $143-166,1993$.

(2). Jacobs, James A., Kilduff, Thomas, F., Materials Engineering Technology, Third Edition, Prentice Hall, 1997.

(3). Dieter, George F., Engineering Design: A Materials and Processing Approach, Second Edition, McGraw-Hill, Page $241-242$

(4). Ashby, M. F., Material Science and Engineering. Volume 5, page 522, 1989.

2.3.c. Case Study: Materials Selection for the Directional Radar Unit (DRU) Housing via the Digital Logic Approach (DLA) or Weighted Property Index.

The DLA employs a rather simple but effective equation: $\boldsymbol{\gamma}=\sum \boldsymbol{\beta}_{\mathbf{i}} \mathbf{w}_{\mathbf{i}} \ldots .$. Eq. M.S.1

Proceedings of the 2003 American Society for Engineering Education Annual Conference \& Exposition Copyright (C) 2003, American Society for Engineering Education 
$(\gamma)$ is the weighted property index, and is computed for each of the pre-selected materials for the DRU housing such as (1). aluminum 1100, (2). aluminum 3003, (3). aluminum 6006, (4). conductive ABS (acrylonitrile-butadiene-styrene terpolymer) and (5).

aluminum 1100 sheet. The material with the highest $(\gamma)$ value is ranked most suitable for the application under consideration.

$(\boldsymbol{\beta})$ is the "weighted property" or "OBJECTIVE" to be maximized, and in this particular case is based on the pre-selected properties: (i). EMI/RFI, (ii). Costs. (iii). Stiffness, and (iv). Manufacturability, as per Tables T.3 and T.4. In-house expertise was used to determine that these four are the critical parameters for the DRU housing material. The choice material must be injection moldable or machinable; the fabrication method is performance and costs-driven. The DRU housing must exhibit structural integrity, RFI/EMI shielding properties (RFI/EMI ... Radio Frequency Interference and Electro Magnetic Interference ... interference from outside sources can cause unwanted degradation of operation), seamless design to ensure water, dust proof and wrinkle-free characteristics, extraordinary resistance to corrosion and high specific strength. ABS, like most polymeric materials, is naturally non-conductive and has poor EMI/RFI properties but conductive grades are easily produced by "TOLL Compounders" such as RTP Corp., Polymer Resources Ltd. and others via simple modification with filler materials such as powdered metals, carbon black and others.

The weighted property $(\boldsymbol{\beta})$ for the pre-selected materials is derived from the equation:

$(\boldsymbol{\beta})=($ Value of Property of Material/Value of Material with Highest Property Value $) * 100$

\begin{tabular}{|l|c|c|c|c|}
\hline \multicolumn{2}{|c|}{ Table T.3: Actual Property Values of Pre-Selected DRU Housing Materials } \\
\hline \multirow{2}{*}{ Materials } & \multicolumn{5}{c|}{ Properties } \\
\cline { 2 - 5 } & EMI/RFI & COSTS & STIFFNESS & MANUFACTURABILITY \\
\hline $\begin{array}{l}\text { Aluminum } \\
1100 \text { Drawn }\end{array}$ & 90 & 90 & 70 & 80 \\
\hline $\begin{array}{l}\text { Aluminum } \\
\text { 3003 Drawn }\end{array}$ & 90 & 80 & 70 & 70 \\
\hline $\begin{array}{l}\text { Aluminum } \\
\text { 6006 Drawn }\end{array}$ & 90 & 70 & 70 & 60 \\
\hline $\begin{array}{l}\text { Conductive } \\
\text { ABS }\end{array}$ & 80 & 99 & 70 & 80 \\
\hline $\begin{array}{l}\text { Aluminum } \\
1100 \text { Sheet }\end{array}$ & 90 & 50 & 70 & 35 \\
\hline Steel & 90 & 95 & & \\
\hline
\end{tabular}

Proceedings of the 2003 American Society for Engineering Education Annual Conference \& Exposition Copyright (C) 2003, American Society for Engineering Education 
$\left(\mathbf{w}_{\mathbf{i}}\right)$ is the weighting factor, and it is determined by comparing the "objectives", two at a time; the property or "objective" that is considered the more important of the two is given a 1 and the less important property is given a 0 . The total number of possible combinations or comparisons, $\mathbf{N}=\mathbf{n}(\mathbf{n}-\mathbf{1}) / \mathbf{2} ; \mathbf{n}=$ total number of objectives or 4 in this case. Therefore, $\mathrm{N}$ for the DRU housing material selection is: $4(4-1) / 2=6$. The weighting factor procedure is as Table T.5.

\section{3.c-i. DLA Results}

The $(\beta)$ and $\left(\mathrm{w}_{\mathrm{i}}\right)$ values from Tables T.4 and T.5 respectively are put into equation M.S.1. to generate the weighted property index $\left(\gamma_{\mathrm{i}}\right)$ for each of the pre-selected materials under evaluation. The generated $\left(\gamma_{i}\right)$ values are as follows: conductive $\mathrm{ABS}=96.3$; drawn aluminum $1100=95.5$; steel $=89$; drawn aluminum $3003=88$; drawn aluminum $6006=$ 81 ; sheet aluminum $1100=67$.

\begin{tabular}{|l|c|c|c|c|}
\hline \multicolumn{2}{|c|}{ Table T.4: Weighted Property ( $\beta)$ Values of Pre-Selected DRU Housing Materials } \\
\hline \multirow{2}{*}{ Materials } & \multicolumn{4}{|c|}{ Properties } \\
\cline { 2 - 5 } & EMI/RFI & COSTS $\left(\boldsymbol{\beta}^{*}\right)$ & STIFFNESS & MANUFACTURABILITY \\
\hline $\begin{array}{l}\text { Aluminum } \\
1100 \text { Drawn }\end{array}$ & 100 & 91 & 87.5 & 100 \\
\hline $\begin{array}{l}\text { Aluminum } \\
\text { 3003 Drawn }\end{array}$ & 100 & 81 & 87.5 & 87.5 \\
\hline $\begin{array}{l}\text { Aluminum } \\
6006 \text { Drawn }\end{array}$ & 100 & 70.7 & 87.5 & 75 \\
\hline $\begin{array}{l}\text { Conductive } \\
\text { ABS }\end{array}$ & 89 & 100 & 87.5 & 100 \\
\hline $\begin{array}{l}\text { Aluminum } \\
1100 \text { Sheet }\end{array}$ & 100 & 50.5 & 87.5 & 50 \\
\hline Steel & 100 & 96 & 100 & 44 \\
\hline
\end{tabular}




\begin{tabular}{|c|c|c|c|c|c|c|c|c|c|}
\hline \multicolumn{2}{|c|}{ Property } & \multicolumn{6}{|c|}{ Possible Combinations or Comparisons (N) } & \multirow{3}{*}{$\begin{array}{l}\text { Positive } \\
\text { Decisions }\end{array}$} & \multirow{3}{*}{$\begin{array}{l}\text { Weighting } \\
\text { Factor } \\
\left(\mathrm{w}_{\mathrm{i}}\right)\end{array}$} \\
\hline \multirow{2}{*}{\multicolumn{2}{|c|}{$\downarrow$}} & $\mathrm{i}$ & ii & iii & iv & $\mathrm{V}$ & vi & & \\
\hline & & (1)(2) & $(1)(3)$ & $(1)(4)$ & $(2)(3)$ & (2)(4) & $(3)(4)$ & & \\
\hline 1 & EMI/RFI & 0 & 1 & 1 & & & & 2 & 0.333 \\
\hline 2 & Costs & 1 & & & 1 & 1 & & 3 & 0.500 \\
\hline 3 & Stiffness & & 0 & & 0 & & 0 & 0 & 0.000 \\
\hline 4 & $\begin{array}{l}\text { Manufact- } \\
\text { urability }\end{array}$ & & & 0 & & 0 & 1 & 1 & 0.167 \\
\hline & Total & & & & & & & 6 & 1.0 \\
\hline
\end{tabular}

2.3.d. Case Study: Materials Selection for the Signal Detector Control Head Unit (SDCHU) Housing via Life Cycle Value Analysis (LCVA).

As in the case of the DRU discussed above, the search for the SDCHU housing material yielded several suitable materials with ABS (acrylonitrile-butadiene-styrene) terpolymer and aluminum 1100 as the top two choices. Life cycle value analyses (LCVA) were carried out on the SDCHU with ABS and aluminum 1100 as the housing materials respectively, in an attempt to study the long-term perspective, durability, economic and environmental impact of the SDCHU.

The LCVA process comprises of six main phases:

1. Goals of intended Life Cycle Study (LCS),

2. Scope of Intended Life Cycle Study (LCS),

3. Life Cycle Inventory (LCI),

4. Impact Assessment,

5. Interpretation Life Cycle Study Results, and

6. Process or System Improvement.

The SETAC (Society for Environmental Toxicology and Chemistry), ISO (International Standards Organization) and other databases ${ }^{(26)(27)(28)(29)(30)}$ provide very adequate guidelines and detailed procedure on how to carry out a successful life cycle value analysis. The system under study is the SDCHU. The Life Cycle Inventory (LCI) of the SDCHU was implemented using such softwares as Unigraphics' Solid Edge, for "Bill of Materials" (not shown) generation and Green Design Initiative's (EIOLCA) ${ }^{(25)(29)}$. The Impact Assessment of the SDCHU was implemented via use of the EIOLCA and ECO-IT softwares ${ }^{(29)(30)}$. Impact assessment involves evaluation of potential resource depletion, health and environmental consequences of product implementation. Impact Assessment has three main stages: Classification and Characterization, Normalization, and

Proceedings of the 2003 American Society for Engineering Education Annual Conference \& Exposition Copyright (C) 2003, American Society for Engineering Education 
Evaluation. The ECO-IT software by Pre Consultants looks at the impact of a given system or design at three levels, production, use and disposal.

\section{3.d-i. LCVA Results}

Table T.6 shows the LCVA-impact assessment results for the SDCHU with ABS and aluminum as the housing materials. The results on Table T.6 indicate that aluminum housing for the SDCHU yields higher environmental and economic impact in all the eight impact categories studied with the exception of the hazardous waste category; energy usage for the SDCHU with ABS housing is 6.47E-04 MKw-Hr compared to $1.353 \mathrm{E}-03$ $\mathrm{MKw}-\mathrm{Hr}$ for SDCHU with aluminum housing, conventional pollutants for the ABSbased SDCHU is 5.87E-03 metric tons and 1.118E-02 metric tons for SDCHU with aluminum housing, hazardous waste due to SDCHU with ABS housing is 3.02E-02 metric tons and 2.866E-02 metric tons for SDCHU with aluminum housing, and the total costs for ABS-based SDCHU is $\$ 1412$ and $\$ 1770$ for the aluminum-based SDCHU.

\begin{tabular}{|c|c|c|c|c|}
\hline \multicolumn{5}{|c|}{$\begin{array}{l}\text { Table T.6: LCVA - Impact Assessment Results For The SDCHU With ABS And } \\
\text { Aluminum } 1100 \text { Housings }\end{array}$} \\
\hline & \multicolumn{2}{|c|}{ Housing Material Type } & \multirow[b]{2}{*}{ Status * } & \multirow[b]{2}{*}{$\begin{array}{c}\text { Percentage } \\
\text { Change * }\end{array}$} \\
\hline Impact Type $\downarrow$ & $\mathrm{ABS}$ & $\begin{array}{l}\text { Aluminum } \\
1100\end{array}$ & & \\
\hline $\begin{array}{l}\text { Electricity } \\
\text { Used } \\
(\mathrm{MKw}-\mathrm{Hr})\end{array}$ & $6.47 \mathrm{E}-04$ & $1.353 \mathrm{E}-03$ & Increase & 109 \\
\hline $\begin{array}{l}\text { Conventional } \\
\text { Pollutants } \\
\text { (Metric Tons) }\end{array}$ & $5.87 \mathrm{E}-03$ & $1.118 \mathrm{E}-02$ & Increase & 90.5 \\
\hline $\begin{array}{l}\text { Green House } \\
\text { Gases }\left(\mathrm{CO}_{2}\right) \\
\text { (Metric Tons) }\end{array}$ & $2.69 \mathrm{E}-01$ & 4.054E-01 & Increase & 50.7 \\
\hline $\begin{array}{l}\text { Fuels Used } \\
\text { (Metric Tons) }\end{array}$ & $1.04 \mathrm{E}-01$ & $1.567 \mathrm{E}-01$ & Increase & 66.4 \\
\hline $\begin{array}{l}\text { Ores Used } \\
\text { (Metric Tons) }\end{array}$ & $1.36 \mathrm{E}-01$ & $1.482 \mathrm{E}-01$ & Increase & 8.97 \\
\hline $\begin{array}{l}\text { Hazardous } \\
\text { Waste (Metric Tons) }\end{array}$ & $3.02 \mathrm{E}-02$ & $2.866 \mathrm{E}-02$ & Decrease & 5.10 \\
\hline $\begin{array}{l}\text { Water Used } \\
\text { (Billion Gals.) }\end{array}$ & $2.00 \mathrm{E}-06$ & $3.00 \mathrm{E}-06$ & Increase & 50.0 \\
\hline Total Costs & $\$ 1412$ & $\$ 1770$ & Increase & 25.4 \\
\hline
\end{tabular}




\section{Discussion of Results}

The "normalization" of resulting data is key to the "innovativeness" of the advanced materials selection techniques being addressed in this paper; normalization makes use of the weighted property system (WPS) and takes into account the variability in the levels of contribution by the different, pre-selected properties and parameters. Normalization (26)(28)(29)(30)(31) minimizes error, and makes it easy to compare and evaluate competing materials on an equivalent basis. With normalization, impact results are divided by a reference value; typically, this reference value is the total impact value for the category under consideration. The normalization or benchmarking scheme is comparable to the contributing share of a product system to the GNP/GDP.

The DLA generated $\left(\gamma_{\mathrm{i}}\right)$ values of 96.3 for conductive, 95.5 for drawn aluminum 1100, 89 for steel, 88 for drawn aluminum 3003, 81 for drawn aluminum 6006 and 67 sheet aluminum 1100, ranks these materials in order of suitability for the DRU housing. The relatively close weighted property index values for ABS and drawn aluminum 1100 make these two materials equally suitable for the DRU housing. The DRU producing company may decide to capitalize on its vast and already established experience in aluminum processing, or may seize this opportunity to stake its claim in the ever-growing plastics industry.

In the life cycle value assessment of the SDCHU, the 5.1\% decrease in hazardous waste generated due to aluminum use is heavily offset by the 25 to $109 \%$ increase in the other impact categories including costs. Data on Table T.6 indicate that the SDCHU with aluminum housing is more expensive than the SDCHU with ABS housing. Normalized data from the ECO-IT output show that SDCHU with aluminum housing has impact data of 110, 46 and -60 in the production, use and disposal phases respectively, and for a total impact score of $96 \mathrm{mPt}$ (ECO-IT milli-points). ABS housing based SDCHU has scores of 101, 22 and -38 or a total of $85 \mathrm{mPt}$. The disposal stage is scored negatively to represent the concept that recycled material or energy is equivalent to new material. Any amount of material that is recycled or reclaimed is equivalent to an equal amount of new material that is not mined, used or that is conserved. The high values of impact in the production phase of the aluminum and ABS options, $110 \mathrm{mPt}$ and $101 \mathrm{mPt}$ respectively suggest that the production phase of the SDCHU is the most viable area for process or system improvement.

\section{Conclusions}

This paper has demonstrated the implementation of the digital logic approach (DLA) and the life cycle value analysis (LCVA) methodologies for the materials selection of the directional radar unit (DRU) and signal detector control head unit (SDCHU) housings respectively. The use of the weighted property system (WPS) by the DLA and LCVA techniques is innovative; normalization of generated data provides a very simple but valid method for evaluating pre-selected materials in a given application on an equivalent (benchmarked) basis. 
The online availability and accessibility of LCVA softwares such as EIOLCA and ECO-it make it possible to utilize these as tools for teaching and learning the concepts of life cycle value analysis. Government and product marketing (ECO-Labeling) are the driving forces for corporations and organizations engaging in life cycle value assessment of their products and systems.

It is this paper's position that the costs/performance-importance of materials in product, process and system' design and development dictate that material selection be accorded priority and more attention in engineering technology and SMET curricula and education.

Bibliography

1. Ashby, Michael. F., "Materials in Mechanical Design", Journal of Materials Education, Vol. 15, Page $143-166,1993$.

2. Jacobs, James A., Kilduff, Thomas F., Materials Engineering Technology, Third Edition, Prentice Hall, 1997.

3. Dieter, George F., Engineering Design: A Materials and Processing Approach, Second Edition, McGraw-Hill, Page 241 - 242.

4. Bartolotta, Paul, "Materials Processing Technology Transferred to Industry", Aerospace Technology Innovation-Special Edition, Volume 8, Number 2, March/April 2000.

5. "High Performance Metals for the Aerospace Industry: Keeping Costs to Ground", http://www.transtarmetals.com/aero.html

6. "Industrial Production managers", http://www.collegegrad.com/careers/manag19.shtml

7. Ibeh, Christopher, C., Bhattarai, D., "Materials Selection", Advanced Engineering Materials Lecture Series, Pittsburg State University, http://www.geocities.com/ETECH880/

8. Marsden, Will, "Information Management for Aerospace Materials," Advanced Materials \& Processes, June 2002, Volume 160, No. 6, Pages $37-39$.

9. http://www.matweb.com

10. http://www.plasticsusa.com

11. http://www.sdplastics.com

12. Budinski, Kenneth, G., Budinski, Michael, K. "ceramics for Structural Applications," Engineering Materials: Properties and Selection," Sixth Edition, Prentice Hall, 1999, Pages $239-255$.

13. Manas, Chanda, Salil, Roy, K., "Typical Properties of Polymers Used for Molding and Extrusion," Plastics Technology Handbook", Marcel Dekker, Inc., 1986, Pages 517 - 532.

14. Rodriguez, Fernandez, "Selected Properties of Polymer Systems," Principles of Polymer Systems,McGraw Hill, Second Edition, 1982, Pages 531 -545.

15. Ashby, M. F. Material Science and Engineering, Vol. 5, Page 522, 1989.

16. Dieter, George F., Engineering Design: A Materials and Processing Approach, Second Edition, McGraw-Hill, Page 250 - 259.

17. Ashby, M., F., Cebon, D., "New Approaches to Materials Education," Cambride University, March 2002.

18. http://www.gepolymerland.com

19. http://www.steelforge.com

20. http://www.ceramics.com/

21. http://advmat.com/othsites.html

22. http://www.compositesreg.com/

Proceedings of the 2003 American Society for Engineering Education Annual Conference \& Exposition Copyright (C) 2003, American Society for Engineering Education 
23. Grandhi, Ramana, "Computational Nonlinear Aeroelasticity for Multidisciplinary Analysis \& Design," http://www.cs.wright.edu/ lfinkel/ecsresearch/amaeroelasticity.html

24. Ibeh, Christopher, C., Schultz, Mark, Ostmeyer, Jessica, Spencer, Brooklyn, "J-Integral Method for Fracture Toughness of Composites," Unpublished.

25. Shultz, M., Kustom Signals Inc., http://wwwkustomsignals.com

26. Society of Environmental Toxicology and Chemistry (SETAC), http://www.setac.org/

27. ISO 14000 Concepts, http://www.trst.com/gapanal.htm

28. "life Cycle Value Assessment (LCVA), http://www.pembina.org

29. Green Design Initiative, http://www.eiolca.net

30.http://www.pre.nl/life cycle assessment/impact assessment.htm

31. Barnthouse et al, "Evolution and Development of the Conceptual Framework and Methodology of Life-Cycle Impact Assessment," http://www.setac.org/files/addendum.pdf, SETAC North American and European Work Groups, January 1998.

Biographical Information of the Authors

CHRISTOPHER C. IBEH

Dr. Christopher Ibeh is a professor of Plastics Engineering Technology at Pittsburg State University, where he teaches courses entitled: thermoplastic resins, thermoset resins, heat transfer, thermodynamics, research topics in polymers and plastics, and advanced engineering materials. Professor Ibeh is the director of the NSF-sponsored REU/RET program at Pittsburg State University. He has a Doctorate from the Department of Chemical Engineering at Louisiana Tech University, Ruston, LA.

DHIRENDRA BHATTARAI

Mr. Dhirendra Bhattarai is an "innovation graduate scholar" at Pittsburg State University, and is a candidate for the masters in engineering technology degree. He is currently enrolled in the advanced engineering materials course, and implemented the life cycle value analysis on the signal detector control head unit. Dhirendra obtained his bachelor of science degree in electrical engineering from St. Louis University, Philippines. 